\title{
Corruption-breeding political patronage an albatross - former E-Cape health chief
}

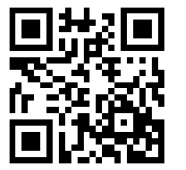

As long as political parties decide who represents us, corruption-breeding patronage will persist - as is best illustrated by the Eastern Cape's virtually collapsed healthcare delivery system. For provinces which mainly incorporated rural apartheid 'homelands' into their administrations, another albatross around their necks is the historical lack of restitution via pure per capita-based budget allocations from central government.

These are the views of Dr Siva Pillay, who recently, and reluctantly, relinquished the reins of healthcare in the dysfunctional Eastern Cape, where lack of delivery equals death for too many of its 7 million residents, and history and indifferent healthcare management are the chief culprits.

Pillay, who is a self-made millionaire and philanthropic businessman as well as a former parliamentarian, was a spirited, corruptionbusting Superintendent General of Eastern Cape Health until December last year, when his contract was suddenly terminated after 2 years and 10 months. Hand-picked by National Health Minister Dr Aaron Motsoaledi to try and solve the seemingly intractable Eastern Cape dilemma, he had fallen foul of the Bhisho political elite who, prior to cutting short his tenure, undermined many of his best delivery initiatives. They also removed most of the administrative functions he had used to overhaul systems and save the taxpayer nearly R1.4 billion in duplicate or corrupt payments. ${ }^{[1]}$ Pillay, an IT expert, persisted, despite surviving a high-speed assassination attempt, a dusk confrontation in a carpark, a sinister burglary of his house and telephonic intimidation of both himself and his wife. Once, outside the Bhisho legislature, he was told by the husband of a sacked chief financial officer (among 1870 crooked healthcare staffers he fired or forced to resign - a national departmental record), 'This is Bhisho - what you sow, you shall reap. The pit we are digging for you is getting deeper and deeper and when we bury you nobody will ever get you out. ${ }^{\text {[2] }}$

Pillay is currently suing the province's 'union-friendly' Health MEC Sicelo Gqobana for R500 000 for defamation. Gqobana claimed in the Eastern Province Herald in January that Pillay penned a controversial memo ordering the non-renewal of

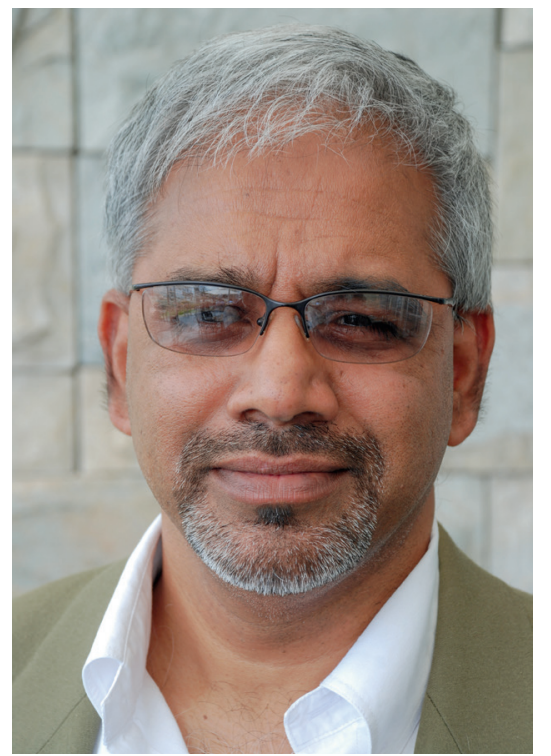

Dr Siva Pillay, former Superintendent General of Health for the Eastern Cape.

contracts for Port Elizabeth Provincial Hospital Cardiology Chief Dr Basil Brown and neurosurgeon Ian Copley. Pillay gave Gqobana 14 days to produce the memo which Gqobana failed to do. Gqobana's claim came in the aftermath of a highly charged confrontation between Port Elizabeth's public sector specialists (several of whom have since resigned in frustration) and Bhisho. The spat began last August, when specialists across disciplines announced that they were unapologetically cutting back on vital patient services to focus only on the very sick and dying. ${ }^{[3]}$ This was in response to far-reaching cutbacks by a provincial health department struggling to manage a R2.5 billion budget shortfall. At the time, Pillay's personnel salary function had been taken over by the provincial treasury and a co-ordinating and monitoring team was vetting all staff appointments.

Pillay has also complained to the Public Service Commission that Gqobana, by re-employing persons who were not registered with the Health Professions Council of South Africa (HPCSA), is placing the department at risk and setting a dangerous precedent. Another charge, which could go to the heart of the corruption debate, is that the MEC improperly interfered with Pillay's functions by entertaining a post-deadline presentation for a lucrative virtual provider network (VPN) tender.
The tender was for a province-wide virtual network linking healthcare facilities. Pillay stormed into Gqobana's office and stopped the presentation.

\section{Naidoo pillories E-Cape leadership}

Pillay's views on the delivery crisis emerged in an Izindaba interview, and in his reply to a scathing online attack on the current Eastern Cape health political elite by Jay Naidoo, a former Mandela-era cabinet minister and former Cosatu Secretary General. For both men, the catalyst was an excoriating report entitled Death and Dying in the Eastern Cape, ${ }^{[4]}$ released after a 2-year probe by the Eastern Cape Health Crisis Action Coalition (ECHCAC) - an alliance of 14 non-governmental organisations (NGOs) including Section 27, the Treatment Action Campaign (TAC), the Rural Health Advocacy Project, the Democratic Nursing Organisation of South Africa (DENOSA) and the South African Medical Association (SAMA).

Naidoo recently joined the board of the Mo Ibrahim Foundation, established to promote African development via good governance. $\mathrm{He}$ said that people 'are dying because the political elites plunder our public coffers and take the precious resources that are supposed to deliver the vital health services our people have a constitutional right to'. He described the theft of R800 million involving Eastern Cape public health officials as 'a monumental cover-up of Watergate proportions', and said the collapsed health system is 'presided over by a parasitic elite that has, for over a decade, abused public trust and used our public coffers as a private slush fund'.

Expressing 'rage', at the contents of the NGO report, Naidoo asked how many doctors and nurses could have been hired, and babies saved via available vaccines and more functional cold chain management, had the stolen money been used properly. He said the report, which used tragic patient tales to put a human face on the hard statistics of delivery dysfunction, was 'a story of political failure'. Naidoo called for decisive action against corrupt bureaucrats, adding: 'We want to see them fired and jailed. We want concrete steps with clear timeframes.'

His disenchantment was matched by that of the Eastern Cape's first post-apartheid Health MEC, Dr Trudy Thomas, who last 
month resigned from the ANC in protest at the 'incompetent politicians and officials' now doing the job. Thomas said Eastern Cape healthcare had gone from 'good to excellent' pre-1994, to a 'full-blown catastrophe' currently. Delivery had progressively deteriorated, 'crashing spectacularly from 2012 - people are dying due to negligence and shortages of drugs and equipment. The government is killing its own people.' Thomas contributed to the NGO report and took part in a protest march to Bhisho.

The report found that the province's health system has 'collapsed', with mismanagement, corruption and patient deaths the order of the day. This state of affairs is aggravated by ongoing official denial, avoidance and abrogation of responsibility. Former Constitutional Court Judge Zak Yacoob, a board member of Section 27, said reading affidavits from patients who suffered the worst horrors 'bring[s] tears to your eyes and make you wonder what can be done to resolve the problem'. ECHCAC said its report was 'not about statistics and numbers, but about people and their pictures - we aim to remind the reader that it is people who suffer the consequences of mismanagement, corruption and indifference'.

\section{First-time mother's horrific experience}

Testimonies included that of Lindeka Gxala, a first-time, 7-month pregnant mother, who made the $10 \mathrm{~km}$ trek to the Pilani Clinic six times but only saw a nurse twice. Eventually Gxala went to Nelson Mandela Hospital in Mthatha, where she learned that her unborn child was dead. At the hospital she shared a bed with another patient thrashing about in labour and bleeding so profusely that blood covered the bed and floor.

Gxala said that after suffering a 'deep, sharp pain, she felt something come out of her. She searched in the darkness for a nurse. 'The nurses ordered me to walk around. I tried to tell them that something was coming out of me, but they told me to walk around more. I kept telling them about the pain. By then my dead child had come out feet first and the head was stuck inside me. The baby hung from me as I walked around, begging them for relief from the pain.' She was given several tablets which made her thirsty. When she went to a sink for water, she found it blocked with vomit. The ward stank of blood and vomit and a friend had to bring her two blankets because the hospital had none for her. She endured 'terrible pain' overnight without any help until 6 am the next day.

Gxala said nurses examining her hospital card commented that they had forgotten to

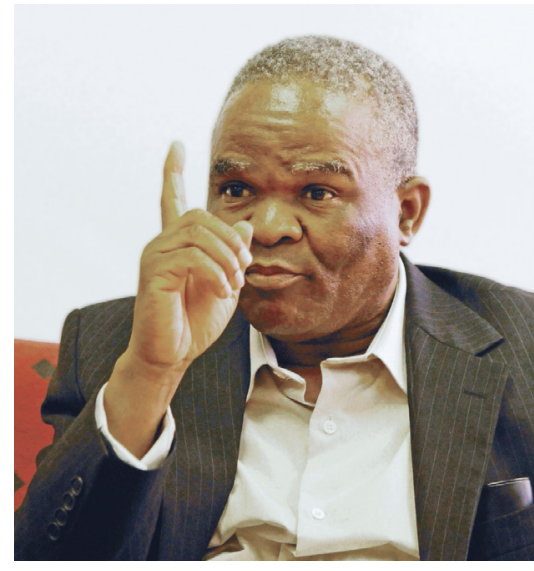

Eastern Cape Health MEC Sicelo Gqobana. Picture courtesy of the Eastern Province Herald.

give her an injectable painkiller. 'I still do not know whether they had forgotten or simply did not have the injection. Without giving me painkillers they then removed the dead baby while I was still conscious. The pain was terrible and they eventually gave me something for the pain, but I had felt everything and cried the whole time.'

\section{More than just corruption - Pillay}

Pillay told Izindaba he doesn't want to downplay the extent of the corruption but feels that 'too many people are jumping on the corruption bandwagon' and blaming it for all the delivery failures. He helped oversee the Special Investigations Unit probe, which exposed the R800 million theft and smashed several crime syndicates and networks with tentacles leading directly into Bhisho. However, he believes the problem is much more systemic - a crippling inheritance of how the former Transkei and Ciskei 'homelands' were incorporated back into South Africa.

Pillay says that when the per capita provincial budget allocations were first made after 1996, little account was taken of the homeland states' infrastructural backlogs, and historical infrastructure and human resource (HR) imbalances were not addressed. 'There was no restitution or equality of service. Remember we only had mission hospitals in the Transkei and Ciskei. So the new provinces that incorporated the former homelands had to use their health budgets for sewerage, electricity [generators], water purification ... whereas in the better-off provinces, the infrastructure was already there'

Landed costs of healthcare goods were also higher, as were HR costs because, paradoxically, rural allowance and subsistence costs were not factored into provincial budget allocations. This meant that retaining healthcare staff via financial incentives actually ended up tearing holes in the province's budget. 'You have to pay them more, but you're not given the money for it!' complained Pillay. Provincial budgeting processes also meant that each province had a different percentage allocation for health (e.g. Western Cape 48\%, Gauteng 44\% and Eastern Cape 28\%).

While praising national treasury for putting into place 'fantastic regulations', Pillay said that the provincial adminstration systems that provinces are mandated to use are mostly 'archaic'. This ranges from the Persal salary system for HR to Logis for procurement systems, the MedSAS system for drugs and BAS for payments. 'There is no integration among these systems', he said. Then there's the lack of technological connectivity. In the Eastern Cape, connectivity is only at $58 \%$, so much administration is paper-based. 'You can (almost) never track or know, what happens. One basic example: we have 920 clinics, of which 242 have no telephones.' One report he commissioned showed that the Eastern Cape's infrastructure amounted to R20 billion, with R750 million needed annually for the "bare minimum' of maintenance. 'Instead we got R100 000 for maintenance annually - that's why facilities like Holy Cross Hospital go to the dogs a mere 12 years after major refurbishment.'

When he was edged out, Pillay had begun rationalising a hugely understaffed servicedelivery platform to match the province's HR and skillset capacity, only to find himself politically undercut. 'For all our facilities 920 clinics, 97 community health centres, 66 district hospitals, 3 regional hospitals, 17 specialised hospitals and seven hospitals forming three urban complexes - we needed another R9 billion just to meet the national human resource norms and standards.' His last HR budget was R16 billion - when he needed R25 billion. 'There is simply no funding to make the expanded delivery service platform work, nor is there the political will to increase the budget or rationalise the service delivery platform to come within budget, he stressed.

Primary healthcare (PHC), encompassing budgets for preventive and promotive healthcare (a major pillar of the national government's pre-national health insurance (NHI) strategy), is 'neither understood nor prioritised'. This was made worse when staff without healthcare backgrounds were appointed to leadership positions, with 'no clue about PHC or its implementation - they think that building more clinics is PHC.

Pillay said that 'slack management and administration' were the other major 
contributors to the overall healthcare delivery dysfunction. There have been five MECs and five heads of department over the past seven years, leaving a fragile department demoralised, uncertain and destabilised. Good managers are 'pushed out,' and those remaining are 'punch drunk, doing what they are told - irrespective of the consequences to the poor and disenfranchised public, who until the advent of the ECHAC were without a voice or advocates'. Pillay said that all boards and committees are currently appointed by the health MEC, and not a single District Health Authority has yet been appointed or established, even in the NHI pilot district.

\section{Only civil society can hold government accountable}

Pillay believes there is no effective opposition party in South Africa, and that civil society has had greater success in holding government to account. 'Our political system - where the political party determines who represents us [in a proportional representation system] cannot be trusted to deliver to the aspirations of society. By its very nature it depends on patronage.' He urged fellow citizens to support the ECHCAC and 'forget the politics and political party affiliation - they all need to be held to account'.

Section 27's executive director, Mark Heywood, summarised Motsoaledi's reaction to the report: it 'shocked him in a number of respects, but most importantly, shocked him into action'. He said the National Health Minister was particularly upset by claims from more outspoken doctors that they had suffered political victimisation. ECHCAC members, speaking at the launch of the report, said most districts in the Eastern Cape had not improved since 1994, with many going backwards and Oliver Tambo district identified as the worst. One study showed that only half of babies aged three months have been immunised, while medical facilities have no water or electricity, suffer stock-outs of basic supplies, have too few staff and too many patients, and have infrastructure in a state of disrepair.

While the report elicited prevarication, equivocation and contradictory responses from Gqobana, Motsoaledi immediately called a press conference outlining all his interventions so far and dispatched an expert team to probe the findings. Confirming that he had long been aware of many of the allegations (which he refused to challenge), Motsoaledi said he was ready to implement several corrective measures, promising that heads would roll wherever corruption and dysfunction were uncovered.

Gqobana, meanwhile, either in person or through his spokesperson, Sizwe Kupelo, repeatedly denied there was any crisis, yet described the problems as being so severe that his department's best efforts had failed. In a radio interview, Gqobana claimed that ECHCAC had cancelled a meeting scheduled with him - which ECHCAC refuted, saying that between 26 July and 11 September this year, Gqobana rescheduled four meetings and cancelled another. Kupelo said the MEC had 'never tried to run away from this group. We have an open door policy for anyone wishing to discuss health matters.'

ECHCAC staged a march to Bhisho early this September, demanding that the provincial health department begin working on 'the key crisis points' within a fortnight. The memorandum also insisted on 'a co-ordinated plan' from the provincial and state departments, with input from the security cluster on corruption. ECHCAC praised Motsoaledi's detailed plans to address the crisis and his frank acknowledgement of many of the problems, including the massive infrastructural backlog in the OR Tambo District and the woeful state of many facilities.

\section{Chris Bateman}

chrisb@hmpg.co.za

1. Bateman C. E Cape's corruption-busting DG finally ousted S Afr Med J 2013;103(4):215-217. [http://dx.doi.org/10.7196/ SAMJ.6862]

2. Bateman C. Corruption busting: A real health threat? S Afr Med J 2011;101(6):360-362.

3. Bateman C. Port Elizabeth's tertiary care reaches crisis point. S Afr Med J 2012;102(9):720-722. [http://dx.doi.org/10.7196/ SAMI.6173]

4. Eastern Cape Health Crisis Action Coalition. Death and Dying in the Eastern Cape: An Investigation into the Collapse of a Health System. East London: ECHCAC, 2013. http://www. section27.org.za/wp-content/uploads/2013/09/SECTION27. report-redacted.pdf (accessed 15 October 2013).

S Afr Med J 2013;103(11):816-818

DOI:10.7196/SAMJ.756 